\title{
PENGEMBANGAN EKSPERIMEN SIMULASI GETARAN DAN GELOMBANG DALAM PEMBELAJARAN SAINS DI SEKOLAH MENENGAH
}

\author{
Yennita $^{1)}$, Ahmad Ma'ruf ${ }^{2}$, Nisa U1 Husni ${ }^{3)}$, Hendar Sudrajat ${ }^{4)}$, Zulirfan $^{5)}$ \\ 1, 2,3,4,5) FKIP Universitas Riau \\ e-mail: yennita_caca@yahoo.com \\ ahmadmaruf257@gmail.com \\ nisaulhusni@gmail.com \\ hendar.sudrajad61@gmail.com \\ zulirfan_aziz@yahoo.com
}

\begin{abstract}
Abstrak
Pembelajaran Sains harus melibatkan pengalaman langsung. Oleh sebab itu siswa harus belajar menemukan bukan belajar dengan metode ceramah. Pembelajaran tentang getaran dan gelombang di dalam tuntutan kurikulum merupakan pembelajaran yang harus dilakukan dengan eksperimen. Namun percobaan ini ternyata sulit dilakukan karena tidak ada alat eksperimen yang dapat menghasilkan gelombang berjalan yang terukur kecepatan, amplitudo, perioda dan frekuensi. Penelitian ini bertujuan untuk mengembangkan alat eksprimen simulasi getaran dan gelombang. Bentuk penelitian ini adalah penelitian pengembangan R\&D yaitu suatu bentuk penelitian yang digunakan untuk menghasilkan produk tertentu dan menguji keefektifan produk. Pengembangan alat percobaan ini mengikuti tahapan ADDIE model, dengan melewati 5 tahap yaitu Analysis, Design, Development, Implementation dan Evaluation. Alat percobaan ini dapat digunakan setelah direvisi, divalidasi oleh pakar. Setelah dinyatakan valid oleh pakar, selanjutnya dilakukan uji coba di lapangan untuk melihat keberfungsian alat dan kemudahan penggunaan alat tersebut. Hasil validasi alat eksperimen dan Lembar Kerja Peserta Didik (LKPD) telah valid menurut pakar. Setelah diuji pada sekelompok siswa, alat eksperimen telah memenuhi kriteria praktis menurut siswa, maka selanjutnya alat ini telah dapat digunakan untuk melihat efektivitasnya.
\end{abstract}

Kata kunci : ADDIE model, getaran dan gelombang, praktikalitas, validitas

\begin{abstract}
Science education must be involved in direct experience. Therefore, student must study with finding problem method not talkative method. Education's module about vibration and wave in curriculum demand, must be accomplish with experient. Unfortunately, this method are difficult to use because the lack of experient tools to produce measured standing waves like velocity, amplitude, period and frequency. The purpose of this research to develop vibration's simulation experiement tool. This research are belong to developing research type, because it was used to producing some products, and testing the effectiveness of a product. The experiment was following ADDIE model steps, which were consist of 5 steps to follow such as analysis, design, development, implementation and evaluation. The experiment tools could be used after validated by the expert. After the validation finished, the tools can be tested in the field. The validation result from experiment tools and Student Worksheets already passed the validation from the experts. After tested in the student's groups, the result were positive and fulfill the criteria practical from students view. Therefore, the tools can be used widely to see its effectiveness.
\end{abstract}

Keywords: ADDIE model, vibration and wave, practicality, validity

\footnotetext{
1) Komunikasi Penulis
} 


\section{Pendahuluan}

Fisika merupakan salah satu bidang Sains yang mengkaji fenomena alam dan interaksi antara fenomena dalam konteks alam, teknologi, manusia dan alam sekitar. Dalam pengajaran fisika, keterlibatan siswa secara aktif merupakan bagian yang penting dalam satu proses pembelajaran. Oleh karena penyajian guru dalam kelas lebih terfokus pada pencapaian target kurikulum, sehingga suasana kelas menjadi tidak bersemangat. Oleh sebab itu siswa hanya menguasai subjek materi dalam jangka waktu pendek tanpa bisa mengaitkan pengetahuan yang mereka peroleh di kelas dengan kenyataan yang ada di sekitar mereka (Zanaton, 2006). Justru proses pengajaran memerlukan pendekatan yang lebih inovatif (Nikitina, 2006; Vebrianto, 2012).

Pendidikan hendaklah jauh ke depan dan memikirkan apa yang akan dihadapi siswa pada masa yang akan datang (Trianto, 2012). Berdasarkan kajian Yennita (2013) tentang hambatan pelaksanaan pratikum di kota Pekanbaru adalah kurang lengkapnya alat dan bahan pratikum. Oleh karena itu pengembangan alat eksperimen menjadi hal yang perlu untuk dikembangkan.

Pembelajaran materi getaran dan gelombang diberikan pada Sekolah Menengah Pertama (SMP) dan Sekolah Menengah Atas (SMA), dimana pada SMP telah diperkenal kan gerak osilasi pada bandul dan pegas. Sebagai pengayaan guru telah menuliskan persamaan osilasi, sedangkan pada SMA materi ini diajarkan lebih dalam lagi, mulai dari persamaan simpangan, kecepatan dan percepatan. Di sekolah, materi ini selalu diajarkan dengan ceramah ataupun dengan menggunakan media bandul untuk melihat peristiwa getaran. Peristiwa getaran ini diterjemahkan dalam bentuk gelombang sinus dengan simpangan $Y=A$ sin $\omega t$. Kesulitan yang terjadi pada siswa adalah menghubung kan antara getaran bolak-balik pada bandul ataupun pegas hingga diperoleh persamaan gelombang sinus. Penelitian ini bermaksud untuk membuat suatu alat percobaan yang memperlihatkan osilasi sekaligus terbentuk nya gelombang sinus tersebut.

Vebrianto \& Kamisah (2012) menyatakan bahwa media pembelajaran yang tidak sesuai, sering menimbulkan masalah pada guru dan siswa dalam menjalankan proses pembelajaran di sekolah, masalah pembelajaran yang sering dihadapi menyebab kan siswa pada umumnya menjadi pasif dan seolah-olah mereka tidak berada dalam proses pembelajaran. Hal ini sesuai dengan pandangan Sudjana \& Rivai (2008) yang menyatakan bahwa tanpa media pembelajaran yang berkesan, siswa masih bisa belajar, tetapi apa yang dipelajari akan mudah dilupakan.

Pembelajaran yang efektif tentunya harus menggunakan media yang berkualitas. Menurut Nasution (2007), media pembelajaran yang baik dan berkualitas haruslah mempertimbangkan beberapa aspek, yaitu validitas, praktikalitas, efisiensi, keamanan dan estetika. Hal yang paling diperhatikan dalam memilih media yang baik dan berkualitas adalah media tersebut haruslah media yang telah divalidkan oleh beberapa ahli yang teruji atau media yang dibuat mampu menyampaikan konsep yang diajarkan. Media yang sudah valid tentunya tidak langsung digunakan oleh guru, namun harus ada praktikalitas media pembelajaran. Praktikalitas merupakan suatu tingkat kemudahan dalam pengunaan media atau alat. Tingkat kepraktisan ini sangat penting dimiliki oleh suatu media yang digunakan dalam percobaan, karena dengan perangkat atau media percobaan tidak akan memerlukan waktu yang cukup lama untuk menemukan konsep fisika, membuat gejala fisika lebih mudah dipahami serta membuat proses pembelajaran menjadi menyenangkan. Oleh karena itu, penggunaan media secara kreatif oleh guru atau pendidik menjadikan siswa lebih banyak belajar, mampu untuk mengingat apa yang dipelajari dengan lebih baik dan meningkatkan kepercayaan diri siswa dalam melakukan kemahiran proses sains.

Berdasarkan penjelasan tersebut, penulis merancang dan membuat perangkat eksperimen simulasi getaran dan gelombang dan Lembar Kerja Peserta Didik (LKPD) yang valid dan praktis. Melalui perangkat eksperimen simulasi konsep getaran dan gelombang yang valid dan praktis dapat digunakan sebagai media pembelajaran fisika.

\section{Bahan dan Metode}


Jenis penelitian ini adalah Research and Development (R \& D). Setyosari (2010) menjelaskan bahwa rancangan penelitian dapat disajikan dalam sebuah model agar dalam penyajiannya informasi yang kompleks atau rumit dengan penjelasan yang panjang-panjang dapat disajikan secara lebih sederhana dan mudah dipahami. Pengembangan media pembelajaran getaran dan gelombang dalam penelitian ini menggunakan model pengembangan ADDIE yang terdiri dari 5 langkah yaitu: Analysis, Design, Development, Implementation dan Evaluation (Maribe Branch, 2009).

Sumber data terdiri dari data untuk keperluan validasi diperoleh dari 5 validator (3 dosen pakar dan 2 guru senior) dan data untuk keperluan praktikalitas diperoleh dari 26 siswa dan 2 guru SMP untuk menilai kemudahan pengguaan alat eksperimen.

Instrumen yang digunakan dalam penelitian ini adalah instrumen untuk menilai alat eksperimen dan Lembar Kerja Peserta Didik (LKPD) yang terdiri:

a. Lembar penilaian validitas alat eksperimen simulasi getaran dan gelombang.

Untuk menilai alat eksperimen simulasi getaran dan gelombang berdasarkan a) fungsi alat, b) kemudahan, dan c) estetika.

b. Lembar penilaian validitas LKPD

Untuk menilai LKPD simulasi getaran dan gelombang berdasarkan a) ketepatan isi, b) bahasa, c) penyajian, dan d) kegrafikan/ tampilan.

Teknik analisis data terdiri dari analisis validitas dan analisis praktikalitas yaitu:

a. validitas

Analisis data hasil validasi mengguna kan langkah-langkah sebagai berikut: mencari skor rata-rata validasi tiap item pertanyaan untuk menentukan kategori validasi tiap item pertanyaan berdasarkan skala likert, setelah itu mencari skor rata-rata tiap indikator. Selanjutnya menentukan kategori skor rata-rata indikator berdasarkan Tabel 1 dengan menggunakan skala Likert.
Tabel 1. Kategori Interpretasi Validitas

\begin{tabular}{cc}
\hline Skor Rata-Rata & Kategori \\
\hline$\geq 4,20-5,00$ & Sangat tinggi \\
$\geq 3,40-<4,19$ & tinggi \\
$\geq 2,60-<3,39$ & Cukup \\
$\geq 1,80-<2,59$ & Rendah \\
$1,0-<1,79$ & Sangat Rendah \\
\hline
\end{tabular}

Jika rata-rata dari setiap indikator penilaian telah berada pada kategori tinggi dan sangat tinggi, maka dapat dikatakan media ini telah valid dan layak untuk digunakan.

b. Praktikalitas

Analisis data hasil praktikalitas menggunakan langkah-langkah sebagai berikut: a) menjumlahkan nilai untuk setiap aspek yang dinilai pada lembar angket (kuesioner) praktikalitas menggunakan skala likert, b) mencari nilai rata-rata tiap aspek penilaian yang diberikan responden, c) menentukan kategori nilai rata-rata aspek penilaian berdasarkan skala likert dan menentukan keputusan praktikalitas setiap aspek penilaian seperti pada Tabel 2 .

Tabel 2. Kategori praktikalitas

\begin{tabular}{|c|c|c|c|}
\hline No & $\begin{array}{c}\text { Skor } \\
\text { rata-rata }\end{array}$ & Kategori & Keputusan \\
\hline 1 & $>3,25-4,00$ & $\begin{array}{l}\text { Sangat } \\
\text { Tinggi }\end{array}$ & Praktis \\
\hline 2 & $>2,50-\leq 3,25$ & Tinggi & Praktis \\
\hline 3 & $>1,75-\leq 2,50$ & Rendah & $\begin{array}{c}\text { Tidak } \\
\text { Praktis }\end{array}$ \\
\hline 4 & $1,00-\leq 1,75$ & $\begin{array}{l}\text { Sangat } \\
\text { Rendah }\end{array}$ & $\begin{array}{c}\text { Tidak } \\
\text { Praktis }\end{array}$ \\
\hline
\end{tabular}

Perangkat percobaan praktis apabila setiap aspek penilaiannya dinyatakan praktis $(>2,5$ hingga $\leq 3,25)$, maka perangkat percobaan telah layak untuk dilakukan uji pemakaian skala yang lebih luas. Apabila aspek penilaian yang secara rata-rata dinilai oleh guru dan siswa dibawah nilai praktis, maka pada aspek penilaian tersebut akan direvisi dan diuji kembali kepraktisannya sampai didapatkan media yang praktis menurut guru dan siswa. 


\section{Hasil dan Pembahasan}

Pengembangan alat eksperimen dan LKPD mengikuti model ADDIE yang setiap tahapnya dijelaskan sebagai berikut:

\section{a. Analisis Keperluan (Analysis)}

Studi pendahuluan yang telah dilakukan terhadap pembelajaran di SMP dan SMA, diperoleh kesulitan siswa dalam menterjemah kan gerakan pada bandul dan pegas terhadap munculnya persamaan gelombang $Y=A$ sin $\omega t$. Kompetensi dasar (KD) pada materi ini, untuk SMP adalah 3.10. Memahami konsep getaran, gelombang, bunyi, dan pendengaran, serta penerapannya dalam sistem sonar pada hewan dan dalam kehidupan sehari-hari dan KD 4.10 Melakukan pengamatan atau percobaan tentang getaran, gelombang, dan bunyi. Kompetensi dasar materi ini, untuk SMA adalah 3.11 Menganalisis hubungan antara gaya dan getaran dalam kehidupan sehari-hari. KD 4.11 Melakukan percobaan getaran harmonis pada ayunan sederhana dan/atau getaran pegas berikut presentasi serta makna fisisnya.

Setelah KD yang bermasalah diketahui, selanjutnya perlu dicarikan solusi atas permasalahan tersebut. Adapun solusi dari permasalahan tersebut adalah melalui perencanaan pembuatan alat yang memperlihatkan gerakan osilasi dan sekaligus munculnya gelombang sinus pada layar.

\section{b. Perancangan (Design)}

Perancangan alat eksperimen ini didasarkan pada rancangan percobaan simulasi seismograf. Kemudian dimodifikasi sedemikian rupa dengan mempertimbangkan estetika, kemudahan dan keamanan saat digunakan. Peneliti berupaya merancang alat eksperimen dengan bentuk yang menarik dan sederhana sebagaimana Gambar 1.

Selain itu, pemilihan alat dan bahan yang digunakan juga menjadi pertimbangan utama. Bahan yang ringan, kuat dan mudah dibentuk seperti akrilik dipilih untuk menjadi kerangka dasar. Berikut rancangan awal alat eksperimen simulasi konsep getaran dan gelombang dapat dilihat pada Gambar 1. Alat ini dapat digunakan pada siswa SMP sebagai pengayaan materi getaran dan gelombang serta untuk di SMA pada awal materi getaran dan gelombang diajarkan.

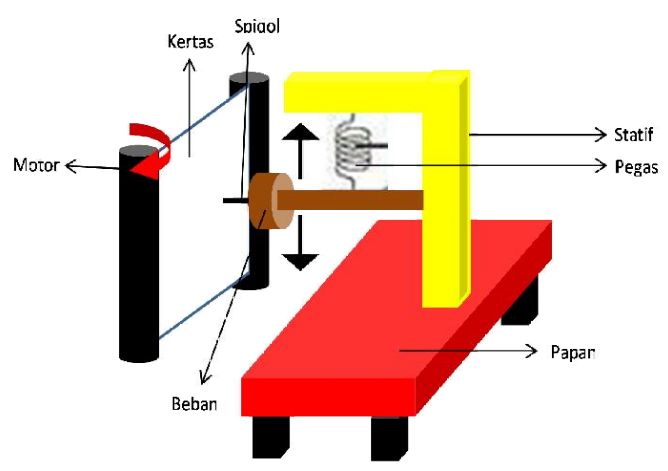

Gambar 1. Rancangan awal alat eksperimen simulasi konsep getaran dan gelombang.

Merancang suatu pembelajaran yang efektif dengan menggunakan strategi yang dapat meningkatkan perbaikan pembelajaran sains sangatlah penting, hal ini sesuai dengan tujuan dari ilmu pengetahuan dan teknologi untuk menyajikan suatu pembelajaran yang berpusat pada siswa dengan lingkungan belajar kognitif dan konstruktivistik, sehingga pembelajaran sains dapat dirasakan lebih menyenangkan bagi pelajar dan tidak kaku (Mehmet, 2012).

\section{c. Pembuatan alat (Development)}

Perangkat eksperimen yang dibuat terdiri dari alat eksperimen simulasi getaran dan gelombang dan LKPD eksperimen simulasi konsep getaran dan gelombang.

1. Alat eksperimen simulasi konsep getaran dan gelombang.

Alat eksperimen simulasi konsep getaran dan gelombang telah dibuat sesuai dengan rancangan dan telah melewati beberapa kali perbaikan baik itu dari segi bentuk dan warna. Alat tersebut dirancang untuk mensimulasikan gelombang. Adapun alat eksperimen simulasi konsep getaran dan gelombang dapat dilihat pada Gambar 2 .

Melalui Gambar 2 dapat dilihat bahwa peralatan eksperimen simulasi konsep getaran dan gelombang terdiri dari beberapa komponen, yakni motor rolling, motor osilator, layar, pena, dimer rolling dan dimer motor. Pena pada alat eksperimen simulasi konsep getaran dan gelombang ini dihubungkan dengan lengan motor AC pada 
bagian landasan bawah meja agar membentuk gelombang.

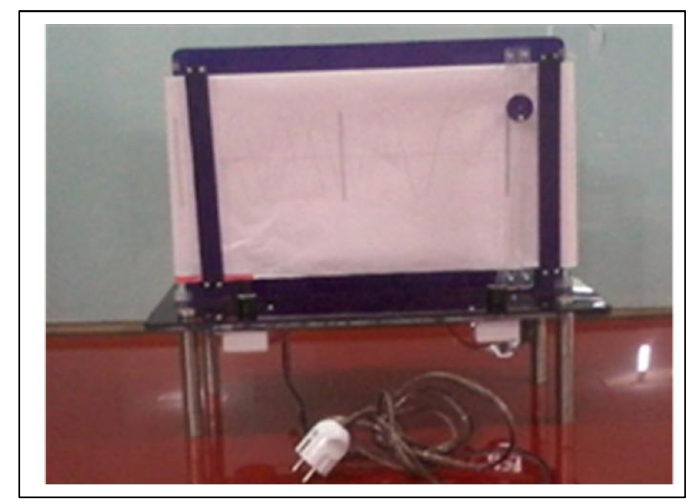

(a)

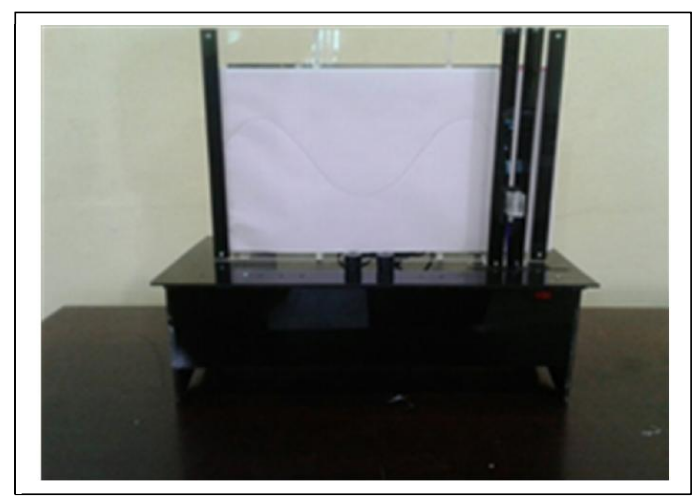

(b)

Gambar 2. Alat eksperimen simulasi konsep getaran dan gelombang Simulasi tenaga motor ac Simulasi tenaga motor kipas.

Penggunaan motor AC pada alat eksperimen dapat divariasikan kecepatan putar motor. Namun, motor ini terlalu cepat dan sulit untuk mengamati bentuk gelombang yang terbentuk. Peneliti mencoba motor simulasi dengan motor kipas yang memiliki 3 (tiga) speed.

Hasilnya, perubahan kecepatan motor tidak tampak perbedaan yang jauh. Sehingga, motor AC dari motor kipas tidak dapat divariasikan frekuensi, perioda, panjang gelombang dan cepat rambat gelombang. Hal ini disebabkan karena pengunaan tegangan PLN yang besar dan motor yang sensitif. Apabila tengangan divariasikan dibawah 220 Volt motor tidak berjalan dengan baik. Namun, perangkat eksperimen ini dapat divariasikan besar amplitudo gelombang dan banyaknya gelombang.

Validasi pertama yang dilakukan pada alat eksperimen simulasi konsep getaran dan gelombang masih mengalami beberapa perbaikan. Perbaikan terhadap alat eksperimen simulasi konsep getaran dan gelombang dilakukan berdasarkan saran-saran yang diberikan validator. Setelah alat selesai diperbaiki maka dilakukan validasi kedua. Pada saat validasi kedua dilakukan validator memberikan nilai terhadap indikator dengan perolehan skor rata-rata validasi sudah mencapai kategori valid. Adapun hasil penilaian validator ditunjukkan pada Gambar 3.

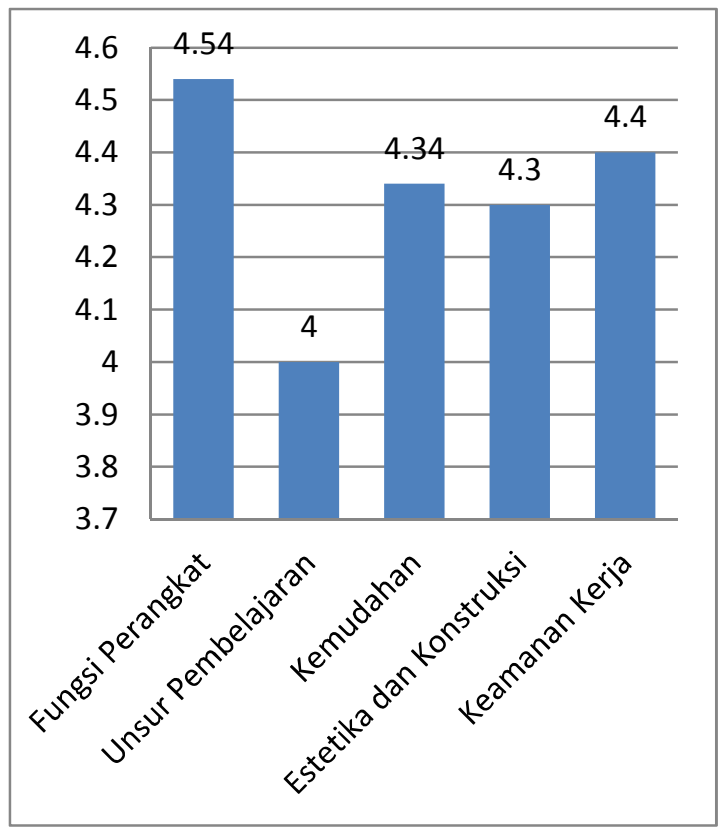

Gambar 3. Validasi alat eksperimen simulasi konsep getaran dan gelombang.

Secara keseluruhan alat eksperimen simulasi konsep getaran dan gelombang sudah dapat dikatakan valid dengan skor rata-rata seluruhnya yaitu 4,27 dengan kategori valid, sehingga alat eksperimen simulasi konsep getaran dan gelombang sudah layak diguna kan sebagai media pembelajaran fisika sekolah menengah. Penggunaan alat ini akan memudahkan guru menerapkan pendekatan ilmiah (scientific). Nurmalaiti (2015) mengatakan bahwa pembelajaran pendekatan ilmiah lebih mampu mendorong siswa dalam 
mengamati, menanya, mencoba atau mengumpulkan data, mengasosiasi atau menalar dan mengkomunikasikan.

\section{LKPD simulasi konsep getaran dan} gelombang

Validasi LKPD dilakukan dengan cara yang sama seperti validasi alat eksperimen. Validasi pertama yang dilakukan oleh validator banyak memberikan saran-saran untuk perbaikan LKPD. Setelah selesai diperbaiki berdasarkan saran-saran validator, maka penggunaan alat eksperimen siap untuk validasi kedua oleh validator. Setelah validasi kedua selesai dilakukan, maka didapatkan hasil skor rata-rata yang sudah valid. Adapun hasil penilaian dari validator dapat dilihat pada Gambar 4.

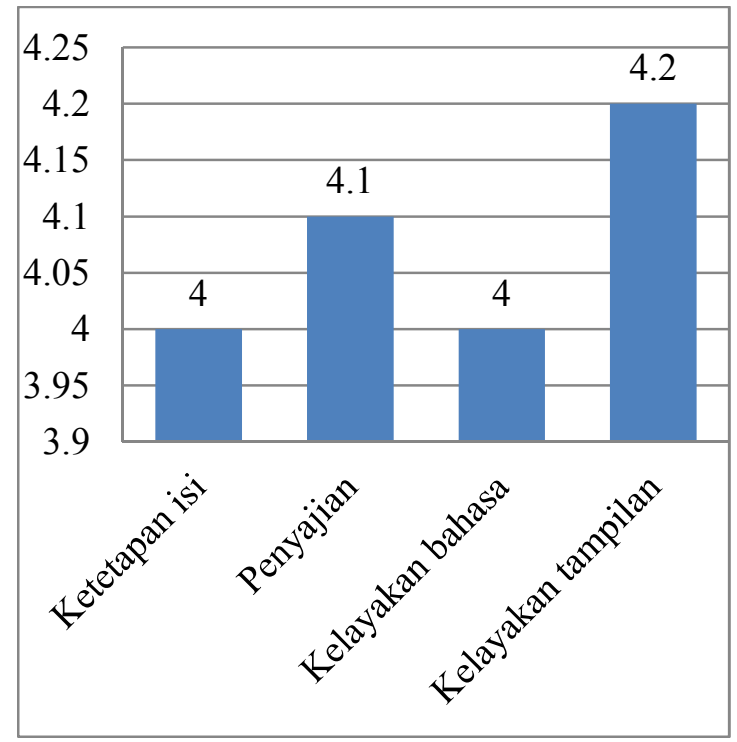

Gambar 4. Validasi LKPD simulasi konsep getaran dan gelombang.

\section{d. Implementasi (Implementation)}

Alat eksperimen dan LKPD yang telah valid menurut pakar, dilanjutkan dengan uji praktikalitas alat percobaan menurut pengguna, dalam hal ini adalah siswa. Tabel 3 adalah hasil uji praktikalitas menurut siswa.

Berdasarkan data pada Tabel 3 menunjukkan bahwa ke 6 indikator praktikalitas alat eksperimen telah berada pada kategori yang layak untuk digunakan pada pengguna yaitu siswa. Aspek praktikalitas menurut siswa diperlukan supaya dalam melakukan eksperimen siswa lebih bisa optimal dan ketrampilan proses dapat berkembang. Keterampilan proses adalah keterampilan fisik dan keterampilan mental terkait dengan keterampilan-keterampilan yang mendasar yang dimiliki, dikuasai dan diaplikasikan dalam suatu kegiatan ilmiah, sehingga para ilmuan dapat menemukan sesuatu yang baru. Menurut Richard \&. Francis (2013) bahwa pembelajaran dengan metode inkuiri dapat dioptimalkan dengan mengaplikasikan keterampilan proses sains siswa. Dengan menggunakan alat eksperimen ini, transfer ilmu langsung dari guru ke siswa. Tetapi dengan adanya interaksi antara siswa, media, dan guru juga akan menumbuhkan perkembangan keterampilan dan sikap ilmiah siswa ke arah yang lebih baik.

Studi penelitian terbaru dalam pengajaran yang efektif, cenderung menunjukkan bahwa mengajar tidak lagi dianggap sebagai proses transfer ilmu pengetahuan dari guru ke siswa, atau dari bahan-bahan pembelajaran kepada siswa, tuntutannya bagaimana pembelajaran menjadi semakin efektif, sehingga memungkinkan berbagai karakter siswa yang berbeda-beda dapat mempelajari materi yang lebih kompleks, mengembangkan keterampilan dengan jangkauan yang lebih luas (Fadzilah et al., 2010).

Berdasarkan Tabel 3 dapat dilihat bahwa, alat telah memenuhi kriteria layak untuk dipakai secara luas, baik dari segi kemudahan, efisiensi waktu, kemudahan pencapaian tujuan, alat eksperimen yang menarik, keamanan penggunaan, petunjuk alat eksperimen dan kemudahan melatih keterampilan siswa. Menurut Darvina (2003), penggunaan media sebagai alat bantu bukan saja dapat menarik minat pelajar untuk mengikuti proses pembelajaran dengan lebih baik, tetapi juga membantu meningkatkan pemahaman siswa dan memudahkan guru menyampaikan ilmu. 
Tabel 3. Praktikalitas alat eksperimen menurut siswa dan guru

\begin{tabular}{llrrrr}
\hline \multirow{2}{*}{ No } & Indikator Praktikalitas Alat Percobaan & \multicolumn{3}{c}{ Menurut Siswa } & \multicolumn{2}{c}{ Menurut Guru } \\
\cline { 3 - 6 } & Simulasi Getaran dan Gelombang & $\mathbf{\%}$ & Kategori & $\mathbf{\%}$ & Kategori \\
\hline 1 & Kemudahan administrasi & 81 & Sangat mudah & 73 & Mudah \\
2 & Efisiensi Waktu & 78 & Efisien & 80 & Efisien \\
3 & Tujuan pembelajaran dapat dicapai & 80 & Mudah & 80 & Mudah \\
4 & Alat eksperimen menarik perhatian siswa & 87 & Sangat Menarik & 90 & Sangat Menarik \\
5 & Keamanan penggunaan & 90 & Sangat Aman & 85 & Sangat Aman \\
6 & Pemahaman petunjuk alat eksperimen & 79 & Mudah & 80 & Mudah \\
7 & Melatih keterampilan siswa & 78 & Mudah & 80 & Mudah \\
\hline
\end{tabular}

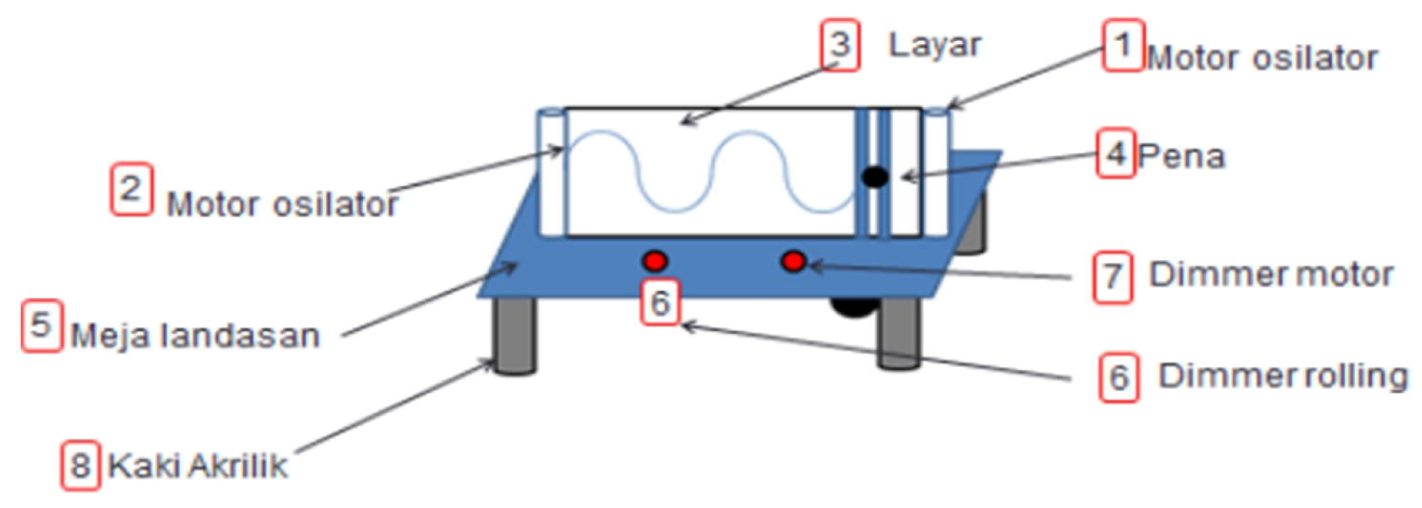

Gambar 5. Bagan alat percobaan.

\section{Kesimpulan dan Saran}

Perangkat eksperimen simulasi konsep getaran dan gelombang telah berhasil dirancang dan dibuat. Proses pembuatan sesuai dengan prosedur Research and Development $(R \& D)$. Adapun rancangan dari perangkat eksperimen terdiri dari alat eksperimen dan LKPD. Hasil penilaian validasi oleh validator terhadap perangkat eksperimen simulasi konsep getaran dan gelombang yang dibuat dinyatakan valid dengan rata-rata skor validitas alat eksperimen sebesar 4,27 dengan kategori valid dan rata-rata skor validasi LKPD sebesar 4,1 dengan kategori valid.

Hasil uji praktikalitas alat simulasi gelombang dan LKPD dinyatakan telah praktis menurut siswa dan guru. Oleh sebab itu, perangkat eksperimen simulasi konsep getaran dan gelombang ini dinyatakan sudah layak digunakan sebagai media pembelajaran fisika.
Sebagai rekomendasi dari peneliti, perangkat eksperimen simulasi konsep getaran dan gelombang yang sudah dibuat ini dapat dilanjutkan untuk menguji efektivitas alat ke sekolah-sekolah, sehingga dapat diketahui apakah alat ini efektif digunakan di sekolah. Untuk perbaikan alat perlu adanya motor lambat dengan kecepatan bervariasi, sehingga variabel frekuensi dapat divariasikan.

\section{Daftar Pustaka}

Darvina Omar, 2003. Kajian pembangunan dan penilaian bahan pembelajaran berbantukan komputer berasaskan cd interaktif bagi mata pelajaran pemasaran 1 di Politeknik. Tesis Sarjana, Kolej Universiti Teknologi Tun Hussein Onn.

Fadzilah A.,R, Jon Scaife, Nurul Aini Yahya \& Habibah Ab Jalil, 2010. Knowledge 
Of Diverse Learners Implications For The Practice of Teaching. International Journal of Instruction, 3(2), pp.83-96. ISSN: 1308-1470, e-ISSN: 1694-609X.

Maribe Branch. R., 2009. Instructional Design : The ADDIE Approach. ISBN 978-0387-09505-9, e-ISBN 978-0-387-095066. Springer, New York.

Mehmet Nuri Gömleksiz, 2012. Elementary School Students' Perceptions of the New Science and Technology Curriculum by Gender. International Forum of Educational Technology \& Society, 15(1), pp.116126. ISSN 1436-4522.

Nasution Noehi, dkk., 2007. Pendidikan IPA di $S D$. Universitas Terbuka, Jakarta.

Nikitina. S., 2006. Three strategies for interdisciplinary teaching: contextualizing, conceptualizing, and problem centring. Journal Curriculum Studies, 38(3), 251-271.

Nurmalaiti, 2015. Pengembangan Perangkat Pembelajaran Fisika SMA Materi Suhu dan Kalor Terintegrasi Thermoregulasi pada Manusia Berbasis Problem Based Learning. Edu Sains, 4(2). (Online). http://ejournal.unp.ac.id.

Richard Owino Ongowo. Francis Chisakwa Indoshi, 2013. Science Process Skills in the Kenya Certificate of Secondary Education Biology Practical Examinations. Scientifik Research An Academic Publisher, 4(11), pp.713-717.

Setyosari, P., 2010. Metode penelitian pendidikan dan pengembangan. Kencana Prenada Media Group, Jakarta.
Sevilay Karamustafaoglu, 2011. Improving the Science Process Skills Ability of Science Student Teachers Using I Diagrams. Eurasian journal of physics and chemistry education, 3(1), pp.26-38. ISSN: 1306-3049.

Sudjana \& Rivai Ahmad, 2008. Media Pengajaran (Penggunaan dan Pembuatannya). Sinar Baru Algensindo, Bandung.

Trianto, 2012. Model Pembelajaran Terpadu. Bumi Aksara, Jakarta.

Vebrianto. R. \& Kamisah, O., 2012. Keberkesanan Penggunaan Pelbagai Media Pengajaran dalam Meningkatkan Kemahiran Proses Sains dalam Kalangan Pelajar (The Effectiveness of Various Instructional Media in Improving Students' Science Process Skills). Jurnal Pendidikan Malaysia, 37(1), 1-11.

Widly Purwanti, 2012. Learning Cycle sebagai Upaya Menciptakan Pembelajaran Sains yang Bermakna. Prosiding Seminar Nasional Penelitian Pendidikan dan Penerapan MIPA. Fakultas MIPA UNY, Yogyakarta.

Yennita, Mugi Sukmawati, Zulirfan, 2012. Hambatan pelaksanaan pratikum yang dihadapi guru SMP Negeri di kota Pekanbaru. Jurnal Pendidikan, 3(11). ISSN 1978-502X.

Zanaton Hj Ikhsan, Lilia Halim \& Kamisah Osman, 2006. Sikap terhadap Sains dalam Kalangan Pelajar Sains di Peringkat Sekolah Menengah dan Matrikulasi Pertanika. Journal of Sosial Science \& Humanities, 14(2), 131-147. 